\title{
Changes in Antioxidant Enzyme Activities of European Mistletoe (Viscum album L. subsp. Album) Leaves as a Response to Environmental Stress Caused by Pollution of the Atmosphere by Nitrogen Dioxide
}

\author{
Jacek Patykowski ${ }^{1 *}$, Jeremi Kołodziejek ${ }^{2}$ \\ ${ }^{1}$ Department of Plant Physiology and Biochemistry, Faculty of Biology and Environmental Protection, \\ University of Lodz, Banacha 12/16, 90-237 Lodz, Poland \\ ${ }^{2}$ Department of Geobotany and Plant Ecology, Faculty of Biology and Environmental Protection, University of Lodz, \\ Banacha 12/16, 90-237 Lodz, Poland
}

Received: 10 September 2015

Accepted: 24 November 2015

\begin{abstract}
In the present study we investigated the seasonal pattern of activity of antioxidant enzymes such as superoxide dismutase (SOD) catalase (CAT) ascorbate peroxidase (APX), guaiacol peroxidase (POD) and syringaldazine peroxidase (SPOD) as well as the total protein concentration in the European mistletoe (Viscum album L. subsp. album). We studied mistletoe leaves that grew on the selected tree species in different parts the city of Lodz, exposed to a greater or lesser extent to the nitrogen dioxide. Sampling campaigns were conducted during the growing season 2013 in early May (at the beginning of the growing season) and in November (at the end of the growing season). We showed considerable seasonal variations of antioxidant enzymatic activity and total protein concentrations for all the samples studied. The test parameters varied depending on the host plants exposition to pollution with nitrogen dioxide. The changes in enzymatic activity did not depend on the host plants. In mistletoe leaves greater changes of SOD activity and total protein concentration were observed in autumn. There is correlation between the level of nitrogen dioxide in atmosphere and activities the enzymes. SOD activity was significantly higher in autumn when the host plants were defoliated. Increased CAT activity was observed in late spring. We demonstrated the positive correlation between changes in enzyme activities and the progress of growing season. Increased activities of POD, CAT and APX to a limited extent depended on the place of growing and exposition to air pollution. In late spring activity of the enzymes did not significant grow because of the protective umbrella from host plant leaves preventing the access of nitrogen dioxide to mistletoe. The higher SOD activity in mistletoe is a consequence of oxidative stress causes by nitrogen dioxides evidently observed in the city center. The test parameters, mainly the activity of SOD, can be used in the future as markers of the
\end{abstract}

*e-mail: jacpat@biol.uni.lodz.pl 
environment purity, especially in the autumn and winter when the temperatures are above freezing, and there are no leaves on the trees.

Keywords: stress, Peroxidase, European mistletoe

\section{Introduction}

Plants are exposed to many harmful factors during growth and development. Biotic factors such as bacterial or fungal pathogens, abiotic pollutants of soil and atmosphere, changes of temperature or humidity as well as solar exposure can cause disorders of cell metabolism called oxidative stress [1-7]. These factors disturb respiration processes, which results in generation of excess amounts of reactive oxygen species (ROS) in the form of singlet oxygen $\left({ }^{1} \mathrm{O}_{2}\right)$ and hydroxyl radical $\left(\mathrm{OH}^{\bullet}\right)$ but mainly of superoxide radical $\left(\mathrm{O}_{2}{ }^{--}\right)$and hydrogen peroxide $\left(\mathrm{H}_{2} \mathrm{O}_{2}\right)$ [8-10].

Plants growing in great urban agglomerations are especially vulnerable to the oxidative stress mostly caused by air pollution with sulfur dioxides or nitrogen dioxide. An excess of reactive oxygens can damage structural and enzymatic proteins which is harmful for cellular organels, e.g., DNA [11]. Long-term $(24 \mathrm{~h})$ heat shock $\left(42^{\circ} \mathrm{C}\right)$ causes damage and oxidative stress in Triticum aestivum seedlings and results in overproduction of $\mathrm{O}_{2}{ }^{\bullet-}[12]$. Reactive oxygen species (ROS) can induce leaf senescence, which is executed through the programmed cell death and which plays an important role in plant survival. Persistent oxidative stress leads to death of cells, tissues and finally of whole plants [13].

All plants in order to survive must deal with the oxidative stress and they employ different defensive strategies to reduce harmful effects of ROS overproductions. Antioxidative enzymes such as catalase (CAT), ascorbate peroxidases (APX) and peroxidase measured with guaiacol (GPOD) and superoxide dismutase (SOD) scavenge ROS resulting in oxidative stress.

SOD plays a crucial role because it transforms more reactive and very harmful $\mathrm{O}_{2} \cdot-$ to less reactive $\mathrm{H}_{2} \mathrm{O}_{2}$ which is involved in many important biochemical reactions, e.g., process of lignification of a cell wall.

The European mistletoe (Viscum album L. subsp. album) is an evergreen, hemi-parasitic plant, normally found growing on a variety of trees. Mistletoe plants are able to accumulate $\mathrm{NO}_{2}$ at a larger concentration than host species $[14,15]$. These findings may indicate that $V$. album subsp. album is a higher resistance to the harmful effects of city environment and attacks hosts with lowered viability caused by environmental pollution [16].

Previous studies demonstrated that nitrogen pollution is generally considered an important factor responsible for the decline of vascular plant species in large cities [17]. In the previous report, we documented that nitrogen accelerated mistletoe post dispersal distribution [18].
This work examines the activities of enzymes involved in ROS scavenging. The activities of CAT, APX, and two forms of peroxidases (one measured with guanaco, the other with syringaldazine) were measured. The latter substance is involved in cell wall lignification. CAT triggered disproprotionation of $\mathrm{H}_{2} \mathrm{O}_{2}$ while APX, POD and SPOD used $\mathrm{H}_{2} \mathrm{O}_{2}$ to oxidise bonds as well as ascorbate and phenolic compounds and SOD converts $\mathrm{O}_{2}{ }^{-}$to $\mathrm{H}_{2} \mathrm{O}_{2}$. The enhanced level of total protein content seems to indicate the increase in the above enzymes.

The objective of this study was to investigate the influence of seasons (May and November) on antioxidant activity of $V$. album samples originating from different host trees, located in the city of Lodz as well as to find whether there is correlation between the antioxidant activity $V$. album and $\mathrm{NO}_{2}$ contamination of the air which would allow to use mistletoe as a bio-indicator.

\section{Material and Methods}

\section{Site Description}

Lodz is the third largest city in Poland located at $19^{\circ} 20^{\prime} \mathrm{N} / 19^{\circ} 38^{\prime} \mathrm{E}$ at an altitude of 170 to $284.1 \mathrm{~m}$ a.s.1. in the centre of the country. It covers an area of $293 \mathrm{~km}^{2}$ and in 2014 had about 706.000 inhabitants. The average annual precipitation in the period 1931-1998 ranged between 530 and $580 \mathrm{~mm}$. The average annual temperature (1931-1998) ranged between 7.5 and $8.4^{\circ} \mathrm{C}$ [19].

Acer saccharinum $\mathrm{L}$. is the most common tree $(24.1 \%)$ in the city of Lodz, followed by T. × euchlora, Sorbus aucuparia, Salix alba, and $P$. $\times$ canadensis mainly occurring at the border of the urban area. Frequent forestry newcomers include Robinia pseudoacacia and Acer negundo which are often planted as street trees because they are tolerant towards polluted city air [20]. Acer saccharinum L., $P$. $\times$ canadensis Moench (in the varieties of 'Serotina'. 'Robusta') and $R$. psedoacacia L. are frequently infested with mistletoe [18].

Air pollution in Lodz is a well known phenomenon. Nitrogen oxides $\left(\mathrm{NO}_{x}\right.$, and especially nitrogen dioxide, or $\mathrm{NO}_{2}$ ) are one of the most common air pollutants. For example, from the city centre (nearer the pollutant source) to the outskirts of the city (farther from the source) in the Lodz city $\mathrm{NO}_{2}$ concentrations were high at 52 Drewnowska St. $\left(28.6 \mu \mathrm{g} / \mathrm{m}^{3}\right.$, over $24 \mathrm{~h}$, from January to December in 2013; Regional Inspectorate for Environmental Protection in Lodz) and low $\left(16.2 \mu \mathrm{g} / \mathrm{m}^{3}\right) 6 \mathrm{~km}$ further west near the 144 Aleksandrowska St. (Fig. 1). 


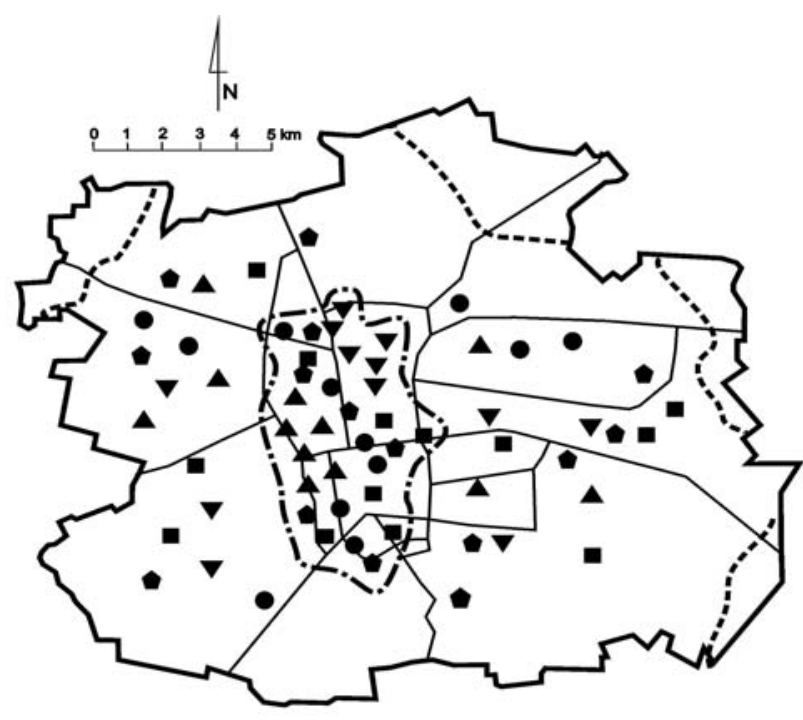

$\mathrm{NO}_{2}$ concentrations

-...-. $16-20 \mu \mathrm{g} / \mathrm{m}^{3}$

ᄂ.-. $24-34 \mu \mathrm{g} / \mathrm{m}^{3}$

- Acer saccharinum

- Populus $\times$ canadensis

- Sorbus aucuparia

- Crataegus laevigata

- Robinia pseudoacacia

Fig. 1. Regression coefficient for SOD and SPOD activities in the leaves of mistletoe from different host trees.

\section{Materials}

\section{Plant Material}

Leaves of $V$. album were harvested in May and November 2013, from different host trees located either in the city centre (very high pollution) or at the outskirts of the city (low pollution). Due to the temperature above zero in both months, mistletoe plants were in a vegetative state. Locations were chosen on the basis of air pollution data from Regional Inspectorate for Environmental Protection in Lodz and terrestrial mapping of mistletoes conducted by Kołodziejek et al. [18]

The following host plant species were selected: Acer saccharinum, Sorbus aucuparia L. emend. Hedl., P. × canadensis cv. 'Robusta', Robinia pseudoacacia and Crataegus laevigata (Poir.) DC. Five isolated or dominating trees per species were chosen in the city centre and in the outskirts. Fully expanded leaves (3-5 leaves) were cut from the south side of the canopy at a height of $1.70-2.50 \mathrm{~m}$ above the ground. A total of 60 plant samples were collected they were kept in a cool box during transport to the laboratory and until the moment of analysis.

\section{Methods}

\section{Enzyme Assays}

Half a gram of the tissue located up to $1 \mathrm{~mm}$ beneath the peel was homogenized in a mortar with ice-cold
$50 \mathrm{mM}$ potassium phosphate buffer $(\mathrm{pH}$ 7.0) containing $10 \mathrm{mM}$ ascorbate, $1 \mathrm{M} \mathrm{NaCl}, 1 \mathrm{mM}$ EDTA and $1 \%$ polvinylpyrrolidone. After centrifugation (20 000 $\times \mathrm{g}, 15 \mathrm{~min}$ ) the supernatant was used to determine the activities of peroxidase, superoxide dismutase and protein contents.

\section{Assay of Peroxidase (EC 1.11.1.7) Activity with Guaiacol and Syringaldazine}

Peroxidase activity with guaiacol (GPOD) was determined by increase in absorbance at $470 \mathrm{~nm}$ $\left(=26.6 \mathrm{mM}^{-1} \mathrm{~cm}^{-1}\right)[21]$. The reaction mixture contained $25 \mathrm{mM}$ acetate buffer $\mathrm{pH}$ 5.6, 5mM guaiacol, $15 \mathrm{mM} \mathrm{H}_{2} \mathrm{O}_{2}$ and enzyme extracts. The addition of $\mathrm{H}_{2} \mathrm{O}_{2}$ started the reaction. Peroxidase activity with syringaldazine (SPOD) was determined spectrophotometrically by an increase in absorbance at $530 \mathrm{~nm}\left(=27 \mathrm{mM}^{-1} \mathrm{~cm}^{-1}\right)$. The reaction mixture contained $25 \mathrm{mM}$ phosphate buffer $\mathrm{pH}$ 6.0, $41.6 \mu \mathrm{M}$ syringaldazine $\left(0.050 \mathrm{~cm}^{3}\right)$ solution $(3.1 \mathrm{mg}$ in $4 \mathrm{~cm}^{3}$ methanol), $0.11 \mathrm{mM} \mathrm{H}_{2} \mathrm{O}_{2}$ and enzyme extracts. The addition of syringaldazine started the reaction.

\section{Assay of Ascorbate Peroxidase (EC 1.11.1.11) Activity}

The APX activity was assayed in extracts from fresh leaves by the Nakano and Asada method [22]. Two $\mathrm{cm}^{3}$ of the reaction mixture contained: $50 \mathrm{mM}$ potassium phosphate buffer of $\mathrm{pH} 7.0,0.05 \mathrm{~cm}^{3}$ of enzymatic extract, $0.05 \mathrm{~cm}^{3}$ of $5 \mathrm{mM}$ the ascorbate. The reaction was initiated by adding $0.10 \mathrm{~cm}^{3}$ of $0.5 \mathrm{mM} \mathrm{H}_{2} \mathrm{O}_{2}$. Activities of enzymes were measured by the reduction of the optical density at wavelength $265 \mathrm{~nm}$ for 5 minutes. To assess activity of APX the following coefficient for ascorbate was used $\varepsilon=13.7 \mathrm{mM}^{-1} \mathrm{~cm}^{-1}$. The amount of enzyme oxidizing $1 \mathrm{mM}$ of ascorbate during 1 minute at $30^{\circ} \mathrm{C}$ was accepted as one unit (U) of the enzyme activity.

\section{Assay of Catalase (EC 1.11.1.6) Activity}

The CAT activity was assayed spectrophotometric according to Dhindsa et al. [23]. $2 \mathrm{~cm}^{3}$ of the incubation mixture contained $50 \mathrm{mM}$ potassium phosphate buffer $\mathrm{pH}$ $7.015 \mathrm{mM} \mathrm{H}_{2} \mathrm{O}_{2}$ and $0.03-0.05 \mathrm{~cm}^{3}$ of the enzymatic extract. The decrease in the $\mathrm{H}_{2} \mathrm{O}_{2}$ concentration was monitored spectrophotometrically at $240 \mathrm{~nm}$ wavelength. To assess activity of CAT the following coefficient for $\mathrm{H}_{2} \mathrm{O}_{2}$ was used $\varepsilon=45.2 \mathrm{mM}^{-1} \mathrm{~cm}^{-1}$.

Disproportionating $1 \mu \mathrm{mol} \mathrm{H}_{2} \mathrm{O}_{2}$ during 1 minute at $30^{\circ} \mathrm{C}$ was accepted as one unit $(\mathrm{U})$ of the enzyme activity.

\section{Assay of Superoxide Dismutase (EC 1.15.1.1) Activity}

The activity of SOD was assayed by measuring its ability to inhibit the photochemical reduction of NBT using the method of Beauchamp \& Fridovich modified by Patykowski and Kołodziejek [19]. Three $\mathrm{cm}^{3}$ of the 
reaction mixture contained $50 \mathrm{~mm}$ phosphate buffer at pH 7.8, 13 mM methionine (Sigma), $75 \mu \mathrm{M}$ NBT, $2 \mu \mathrm{M}$ riboflavin (Sigma), $0.1 \mathrm{mM}$ EDTA (Sigma) and $0.02 \mathrm{~cm}^{3}$ enzyme extract. Riboflavin was added last and the tubes were placed $30 \mathrm{~cm}$ below two $15 \mathrm{~W}$ fluorescent lamps. The reaction was initiated by switching on the light and for $10 \mathrm{~min}$. Switching off the light stopped the reaction and the tubes were covered with a black cloth. The unilluminated tubes were the control. The absorbancies at $560 \mathrm{~nm}$ were read. The volume of extract corresponding to $50 \%$ inhibition of the reaction was considered one enzyme unit.

\section{Assay of Protein Contents}

Proteins were determined by the method of Bradford [24] using bovine serum albumin (Sigma) as a standard.

\section{Statistical Analysis}

Prior to data analysis all data were arcsine square root transformed to correct sample heterogenity. Twoway statistically significant differences between 'seasons' (two levels: spring and autumn) and 'sites' (two levels: the outskirts of a city and the city centre) were calculated under two-way ANOVA. Tukey's multiple comparison post hoc test (HSD-test) was carried out to show significant $(\mathrm{P}<0.05)$ differences between individual treatments. Statistical analysis was carried out using Statistica v. 10 (Statsoft. Inc., 2011).

\section{Results}

The mean values of antioxidant enzyme activities and protein contents in the leaves of mistletoe from different host trees are shown in Table 1.

The specific activities of CAT in spring were almost twice higher than those in autumn. However, the activities of APX, GPOD, SPOD, and mainly of SOD were in general significantly lower in spring than in autumn. It is worth showing that SOD activity increased significantly in the material from all five host plants, while that of APX only in the material from three host species. In autumn, V. album collected from Crataegus had the lowest protein content. Protein content in the leaves of mistletoe hosted by Acer, Populous, and Robinia did not change significantly in different seasons (Table 1). In general, antioxidant activity was higher in autumn than in spring.

The most statistical changes depended on the season and site (Table 2). Correlation between total protein content and enzymatic activities may be of major importance.

Two-way ANOVA indicates that activity of these antioxidant enzymes and total content of protein were significantly affected by seasons $(\mathrm{P}<0.05)$ (Table 2$)$.

It was shown that the regression coefficients for SOD and SPOD were consistent, which indicates an important role of these enzymes for mistletoe functioning (Fig. 2).

The map (Fig. 1) shows the levels of nitrogen dioxide pollution of the atmosphere of where the spaces were collected from the host trees.

\section{Discussion}

Many articles concerning the problem of pollution have been written. Environmental pollution factors include heavy metals [25], dusts, and gases that cause acid rains [26] and other problems. They damage chloroplasts [27], which leads to disturbances of plant growth and development.

Table 1. ANOVA results of antioxidant enzyme activities and protein contents in the leaves of mistletoe from different host trees based on post-hoc mean comparison (Tukey's multiple comparison post hoc test). Data are means \pm SD of 3 replicates $(n=3)$.

\begin{tabular}{|c|c|c|c|c|c|c|c|}
\hline \multicolumn{2}{|c|}{ Constituent } & $\begin{array}{c}\text { CAT } \\
\text { U/g fr.w. }\end{array}$ & $\begin{array}{c}\text { APX } \\
\text { U/g fr.w. }\end{array}$ & $\begin{array}{c}\text { GPOD } \\
\text { U/g fr.w. }\end{array}$ & $\begin{array}{c}\text { SPOD } \\
\text { U/g fr.w. }\end{array}$ & $\begin{array}{c}\text { SOD } \\
\text { U/g fr.w. }\end{array}$ & $\begin{array}{c}\text { Protein } \\
\text { m/1 g fr.w. }\end{array}$ \\
\hline Spring & Viscum/Acer & $0.0589 \pm 0.0242 \mathrm{~b}$ & $0.059 \pm 0.0241 \mathrm{a}$ & $18.16 \pm 7.73 \mathrm{ab}$ & $20.06 \pm 4.19 \mathrm{a}$ & $23.57 \pm 14.54 \mathrm{a}$ & $6.41 \pm 0.94 \mathrm{a}$ \\
\hline & Viscum/Crataegus & $0.0509 \pm 0.0198 \mathrm{a}$ & $0.051 \pm 0.0198 \mathrm{~b}$ & $23.68 \pm 9.09 \mathrm{~b}$ & $22.44 \pm 5.56 \mathrm{a}$ & $24.88 \pm 11.61 \mathrm{a}$ & $6.28 \pm 0.66 \mathrm{a}$ \\
\hline & Viscum/Populus & $0.0461 \pm 0.0004 \mathrm{~b}$ & $0.046 \pm 0.0001 \mathrm{a}$ & $22.81 \pm 9.35 \mathrm{ab}$ & $18.22 \pm 9.35 \mathrm{a}$ & $22.52 \pm 14.64 \mathrm{a}$ & $6.31 \pm 1.13 \mathrm{a}$ \\
\hline & Viscum/Robinia & $0.0389 \pm 0.0008 \mathrm{a}$ & $0.039 \pm 0.0008 \mathrm{~b}$ & $14.48 \pm 0.96 \mathrm{a}$ & $17.43 \pm 2.09 \mathrm{a}$ & $29.09 \pm 5.37 \mathrm{a}$ & $6.28 \pm 0.02 \mathrm{a}$ \\
\hline & Viscum/Sorbus & $0.0494 \pm 0.0174 \mathrm{a}$ & $0.049 \pm 0.0174 \mathrm{a}$ & $19.51 \pm 5.99 \mathrm{ab}$ & $17.97 \pm 5.87 \mathrm{a}$ & $33.32 \pm 12.64 \mathrm{a}$ & $7.37 \pm 1.24 \mathrm{~b}$ \\
\hline Autumn & Viscum/Acer & $0.0066 \pm 0.0023 \mathrm{a}$ & $0.579 \pm 0.126 \mathrm{a}$ & $24.14 \pm 7.54 \mathrm{a}$ & $23.33 \pm 5.06 \mathrm{a}$ & $50.19 \pm 37.33 \mathrm{a}$ & $7.33 \pm 0.95 \mathrm{a}$ \\
\hline & Viscum/Crataegus & $0.0066 \pm 0.0030 \mathrm{a}$ & $0.465 \pm 0.069 \mathrm{a}$ & $26.03 \pm 8.88 \mathrm{a}$ & $23.29 \pm 2.46 \mathrm{a}$ & $39.50 \pm 31.48 \mathrm{a}$ & $6.70 \pm 1.15 \mathrm{~b}$ \\
\hline & Viscum/Populus & $0.0063 \pm 0.0019 \mathrm{a}$ & $0.489 \pm 0.109 \mathrm{a}$ & $26.81 \pm 9.64 \mathrm{a}$ & $18.68 \pm 5.45 \mathrm{a}$ & $26.96 \pm 28.74 \mathrm{a}$ & $7.53 \pm 1.09 \mathrm{a}$ \\
\hline & Viscum/Robinia & $0.0057 \pm 0.0026 \mathrm{a}$ & $0.502 \pm 0.037 \mathrm{a}$ & $17.26 \pm 3.82 \mathrm{a}$ & $22.34 \pm 4.85 \mathrm{a}$ & $21.01 \pm 9.93 \mathrm{a}$ & $7.85 \pm 1.20 \mathrm{a}$ \\
\hline & Viscum Sorbus & $0.0055 \pm 0.0015 \mathrm{a}$ & $0.518 \pm 0.089 \mathrm{a}$ & $24.29 \pm 5.41 \mathrm{a}$ & $19.74 \pm 5.68 \mathrm{a}$ & $51.95 \pm 28.26 \mathrm{a}$ & $7.37 \pm 1.24 \mathrm{a}$ \\
\hline
\end{tabular}

Different letters in each column for the same season indicate significant differences $(\mathrm{P}<0.05)$ across all host trees $(\mathrm{N}=12$ mistletoes per group). 


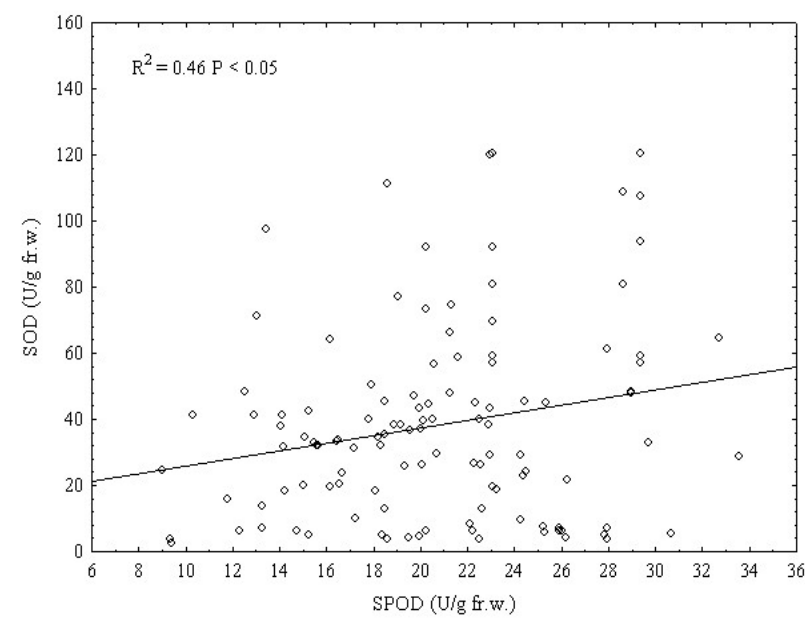

Fig. 2. Sampling sites in Lodz: very high and low pollution areas.

Similarly a lot of research work focused on plant defence mechanisms against pathogens (bacteria and fungi) as well dehydration, low temperature and salinity [28]. All these factors lead to molecular changes.

To the best of our knowledge there is little information concerning enzymatic changes in parasitic and hemiparasitic plants. European mistletoe is a semi-parasitic evergreen shrub, its growth and development are closely adapted to the host $[15,29]$ and seasons of the year $[21,30]$. The seasonal changes of physiological activity of $V$. album are similar to those of woody evergreen species and depend on the development stages of the parasite [31].

It has been shown that mistletoe's influence on hosts was similar to the effect of long-lasting drought stress [32]. It is known that the mistletoe parasite has a huge impact on the transport of primary metabolites in a host plant and has a decisive influence on its growth [33]. During plant-pathogen interactions the deposition of $\beta-1,3$-glucan, triggered by reactive oxygen species [34], leads to callose accumulation in the form of a structural scaffold for toxic molecules [35] and reflects its participation in host self-defence mechanisms. Callose localization in root cells may lead to oxidative burst and host cell death.

Activities of many plant enzyme involved in defence mechanisms were examined after the oxidative stress. We compared the parameters in the material collected in autumn and late spring because in autumn host plants are already deprived of leaves and when temperatures are above zero the mistletoe vegetation is most intensive due to access to light. While in spring host plant leaves deprive mistletoe of sun light.

European mistletoe is highly resistant to the harmful effects of city environment and attacks trees with lowered viability caused by environmental pollution [16]. In the classical research model plants exposed to anthropogenic air pollution, e.g., nitrogen dioxides. The plant defence reaction consists in activation of the enzymes responsible for ROS scavenging. An enhanced level of ROS can cause damage to biomolecules such as lipids, proteins and DNA. These reactions can alter membrane properties like fluidity, ion transport, enzyme activity, protein crosslinking, inhibition of protein synthesis, DNA damage, and so forth ultimately resulting in cell death [6]. The global climates changes brings about novel combinations of severity and timing of different stresses, the effects of which on tree performance are hard to predict. Photosynthesis and growth rates decline with increasing tree age and size, while support biomass in roots, stem and branches accumulates and the concentrations of nonstructural carbohydrates increase. It was suggested that combined stresses can influence survival of large trees even more than chronic exposure to a single predictable stress such as drought [36].

ROS are a hallmark of successful recognition of infection and activation of plant defences [3]. Rai and Agrawal [37] reported that in rice seedlings exposed to high concentrations of nitrogen dioxide, mainly SOD activity (but also those of POD and APX) increased. Hussain and Reigos [38] showed that after treatment of Arabidopsis thaliana seedlings with rutin, a secondary metabolite increases POD activity, which reflected to stress. During oxidative stress have problems homeostasis and normal functioning of the activity of chloroplasts [39]. Kim et al. [40] observed modulation of 20 different peroxidases during rice interaction with the plant-pathogenic fungus Magnaporthe oryzae, which suggests intracellular ROS homeostasis. SOD isoenzymes are essential for scavenging excess reactive oxygen species in living organisms. High SOD activity have been corelated with the generation of $\mathrm{O}_{2}^{-}$radical as a consequence of air pollution with nitrogen dioxides. This enzyme is involved in the metabolism of reactive oxygen species by dismutation of $\mathrm{O}_{2}{ }^{--}$ to molecular oxygen and hydrogen peroxide. Radwan et al. [41] showed that particular isoforms of SOD interacted with other enzymes protecting cells from the oxidative damage. A recent study showed that the expression of genes encoding SOD isoforms may in the future explain the mechanism of stress induction [42].

In plants exposed to pathogens as well as to abiotic stress factors, ROS generation is triggered leading to $\mathrm{H}_{2} \mathrm{O}_{2}$ overproduction [6]. During the host-pathogen interaction the ability to synthesise $\mathrm{H}_{2} \mathrm{O}_{2}$ degrading enzymes such as catalase and peroxidase depends on plant resistance [10, 43]. This proves, that in plants exposed to abiotic stress CAT activity increases most significantly because it is responsible for disproportionation of $\mathrm{H}_{2} \mathrm{O}_{2}$ excess under stress [44]. It can be indirectly involved in the process of deactivation of increased $\mathrm{H}_{2} \mathrm{O}_{2}$ concentrations by different isoforms of peroxidases [43]. Overproduced reactive oxygens such as $\mathrm{O}_{2}{ }^{-}$and $\mathrm{H}_{2} \mathrm{O}_{2}$ are often deactivated already in the apoplastic fraction and this is closly connected with cell wall reconstrution [45]. Peroxidases participate in the process of the cell wall remodeling during oxidative stress $[45,46]$. Activities of special peroxidases responsible for lignification process and for cell wall strengthening are often higher under stress [47]. The activity of peroxidase involved lignification measured with a specific substrate of syringaldazine (SPOD) increased [48]. Especially upon 
Table 2. Two-way of ANOVA effects of season (spring vs. autumn), site (the outskirts of a city vs. the city centre), and their correlation on antioxidant enzyme activity and protein contents in leaves of mistletoe from different host tree.

\begin{tabular}{|c|c|c|c|c|c|c|}
\hline Dependent variable & Source & d.f. & SS & MS & F-value & P-value \\
\hline \multirow{3}{*}{ CAT } & Season & 1 & 0.003 & 0.003 & 9.704 & $<0.001$ \\
\hline & Site & 1 & 0.006 & 0.006 & 0.168 & 0.682 \\
\hline & Season $\times$ site & 1 & 0.006 & 0.006 & 0.015 & 0.902 \\
\hline \multirow{3}{*}{ APX } & Season & 1 & 0.365 & 0.365 & 17.771 & $<0.001$ \\
\hline & Site & 1 & 0.007 & 0.007 & 0.003 & 0.954 \\
\hline & Season $\times$ site & 1 & 0.010 & 0.010 & 0.533 & 0.466 \\
\hline \multirow{3}{*}{ GPOD } & Season & 1 & 479.17 & 479.17 & 9.219 & $<0.001$ \\
\hline & Site & 1 & 83.48 & 83.48 & 0.708 & $<0.05$ \\
\hline & Season $\times$ site & 1 & 36.80 & 36.80 & 0.709 & 0.401 \\
\hline \multirow{3}{*}{ SPOD } & Season & 1 & 259.27 & 259.27 & 10.191 & $<0.01$ \\
\hline & Site & 1 & 116.50 & 116.50 & 4.579 & $<0.05$ \\
\hline & Season $\times$ site & 1 & 111.45 & 111.45 & 4.381 & $<0.05$ \\
\hline \multirow{3}{*}{ SOD } & Season & 1 & 9881.9 & 9881.9 & 15.08 & $<0.001$ \\
\hline & Site & 1 & 7992.2 & 7992.2 & 12.20 & $<0.001$ \\
\hline & Season $\times$ site & 1 & 4087.8 & 4087.8 & 6.246 & $<0.05$ \\
\hline \multirow{3}{*}{ Protein } & Season & 1 & 6.605 & 6.605 & 4.629 & $<0.05$ \\
\hline & Site & 1 & 5.668 & 5.668 & 3.972 & $<0.05$ \\
\hline & Season $\times$ site & 1 & 4.271 & 4.271 & 2.994 & $<0.05$ \\
\hline
\end{tabular}

direct pathogen attack peroxidases (POD) or oxalate oxidases participate in plant defense through reinforcement of plant cell wall [49].

It was shown in this study that SOD activity was generally higer in autumn period and that increased nitrogen dioxide concentration in the atmosphere intensified this process (Tables 1 and 2). We put forward of hypothesis that in mistletoe the high cosntitutive activities of CAT and APX indicated its high adaptability thus it seems that these two enzymes are sufficient for $\mathrm{H}_{2} \mathrm{O}_{2}$ scavenging. That is why no correlation between CAT and APX activities and the level of air pollution was observed. It was shown that the regression coefficients for SOD and SPOD indicated their important role for mistletoe functioning (Fig. 1).

Mistletoe is a hemiparasitic plant able to biosynthesise necessary compounds but it also takes some nutrients from host trees. Vicas et al. [50] showed that aqueous extracts obtained from the leaves of mistletoe had higher antioxidant potentials in autumn than in spring, but this activity depended not only on the harvesting time, but on host trees as well. Low molecular compounds such as phenolic acids and flavonoids were found to be mainly responsible for antioxidant properties of the mistletoe leaves [30]. These authors demonstrated that the differences in antioxidant activity between leaves and stems of mistletoe speciments harvested from different trees could be attributed to environmental factors such as season, climate and temperature which can significantly affect the accumulation of antioxidant components in the plant tissue [30]. Inhibition of oxidative stress generating free radicals and lipid peroxidation was noted in vitro cultured cells after treatment with extracts of mistletoe lectin (KML) [51-52]. These results suggest that KML is a promising antioxidant due to its ability to scavenge free radicals, thus protecting cell against oxidative damage induced by free radicals.

The present study revealed significant influence $(\mathrm{P}<0.05)$ of the season on the antioxidative activities of enzymes (CAT, APX, GPOD, SPOD, SOD) in mistletoe samples originating from different species of trees located in the city of Lodz. We observed a significant decrease in CAT and APX activities in November in comparison with May. The habitat type was significant $(\mathrm{P}<0.05)$ for SPOD and SOD enzyme activities (Table 2) in both periods (May and November). The enzyme activities were higher in the city centre in comparison with the outskirts (Fig. 2). The season also influenced the protein contents in the leaves of mistletoe from different host trees.

We observed the correlation between GPOD, SPOD, SOD and protein contents and sites of growth and season, but no such relationship was observed for CAT and APX (Fig. 1).

The mistletoe reaction to stress is not typical because it may affect host plants similarly to pathogens. However, it 
seems that due to high SOD induction and to the fact that host plants are deprived of leaves, mistletoe functions as a non-parasitic plant. We showed that host plants did not influence SOD activity. The mistletoe grew well in spite of high nitrogen dioxide pollution of the atmosphere.

It still needs elucidation whether mistletoe can be regarded as a biological marker of the environmental pollution with gasses.

\section{Conclusions}

Our study shows that seasonal changes in the activity of antioxidant enzymes in mistletoe occurred independently of the host plant species, and they were higher in the autumn. We believe that especially noticeable higher SOD activity in the leaves of mistletoe growing in the city center the nitrogen dioxide concentration in the atmosphere is high, proving its adaptation to pollution. Mistletoe can perfectly cope in spite of the conditions for increased pollution. We suggest that mistletoe can be used as a biological marker of environmental pollution, toxic gases and the general health of trees.

\section{Acknowledgements}

We thank two anonymous reviewers for their valuable comments and critical reviews of the manuscript.

\section{References}

1. LEE D.H., KIM Y.S., LEE C.B. The inductive responses of the antioxidant enzymes by salt stress in the rice (Oryza sativa L.). J. Plant Physiol. 158, 737, 2001.

2. MAHESHWARI R., DUBEY R.S. Nickel-induced oxidative stress and the role of antioxidant defence in rice seedlings. Plant Growth Regulation. 59, 37, 2009.

3. TORRES M.A. ROS in biotic interactions. Physiol. Plant. 138, 414, 2010.

4. JASPERS P., KANGASJÄRVI J. Reactive oxygen species in abiotic stress signaling. Physiol. Plant. 138, 405, 2010.

5. SWANSON S., GILROY S. ROS in plant development. Physiol. Plant., 138, 384, 2010.

6. SHARMA P., JHA A.B., DUBEY R.S., PESSARAKLI M. Reactive oxygen species, oxidative damage, and antioxidative defense mechanism in plants under stressful conditions. J. Botany 2012, 1, 2012.

7. POSSELL M., LORETO F. The role of volatile organic compounds in plant resistance to abiotic stresses: responses and mechanisms. in Biology, Controls and Models of Tree Volatile Organic Compound Emissions, eds Ü. Niinemets and R. K. Monson (Berlin: Springer Science Business Media B.V.), 209, 2013.

8. NOCTOR G., De PAEPE R., FOYER CH. Mitochondrial redox biology and homeostasis in plants. Trends Plant Sci. 12, 125, 2007.

9. JACOBY R.P., LI L., HUANG SH., LEE CH.P., MILLAR A.H., TAYLOR N.L. Mitochondrial composition, function and stress response in plants. J. Integra. Plant Biol. 54, 887, 2012.
10. SABATER B., MARTIN M. Hypothesis: increase of the ratio singlet oxygen plus superoxide radical to hydrogen peroxide changes stress defense response to programmed leaf death. Fronties Plant Sci. 4, 479, 2013.

11. MOLLER I.M., JENSEN P.E., HANSSON A. Oxidative modifications to cellular components in plants. Ann. Rev. Plant Biol. 58, 459, 2007.

12. SAVICKA M., ŠKUTE N. Effects of high temperature on malondialdehyde content, superoxide production and growth changes in wheat seedlings (Triticum aestivum L.). Ekologija 56, 26, 2010.

13. CHEN X., WANG Y., Li J., JIANG A., CHENG Y., ZHANG W. Mitochondrial proteome during salt stress-induced programmed cell death in rice. Plant Physiol. Biochem. 47, 407, 2009.

14. WATSON D.M. Mistletoe - a keystone resource in forests and woodlands worldwide. Annu. Rev. Ecol. Syst. 32, 219, 2001.

15. ZUBER D. Biological flora of Central Europe: Viscum album L. Flora 199, 181, 2004.

16. ZACHWATOWICZ M., PETROVIĆ K., SUDNIKWÓJCIKOWSKA B. The occurrence of Europea mistletoe under the conditions of high human impact in the central part of Warsaw, Poland. Problemy Ekologii Krajobrazu 22, 101, 2008.

17. KORNECK D., SCHNITTLER M., KLINGENSTEIN F., GERHARD L., TAKLA M., BOHN U., MAY R. Warum verarmt unsere Flora? Auswertung der Roten Liste der Farnund Blütenpflanzen Deutschlands. Schriftenreihe Vegetationsk 29, 299, 1998.

18. KOŁODZIEJEK J., PATYKOWSKI J., KOŁODZIEJEK R. Distribution, frequency and host patterns of European mistletoe (Viscum album subsp. album) in the major city of Lodz, Poland. Biologia 68, 55, 2013.

19. WITOSŁAWSKI P. Atlas of distribution of vascular plants in Łódź. 2006.

20. MOWSZOWICZ J. A systematic review of woody species of Lodz. Zesz. Nauk. Uniw. Łódź 28, 3, 1968 [in Polish].

21. PATYKOWSKI J., KOŁODZIEJEK J. Comparative analysis of antioxidant activity in leaves of different hosts infected by mistletoe (Viscum album L. subsp. Album). Archives Biol. Sci. 65, 851, 2013.

22. Y., ASADA K. Hydrogen peroxide is scavenged by ascorbate-specific peroxidase in spinach chloroplasts. Plant Cell Physiol. 22, 67, 1981.

23. DHINDSA R., PLUMB-DHINDSA P., THORPE T.A. Leaf senescence: correlated with increased levels of membrane permeability and lipid peroxidation, and decreased levels of superoxide dismutase and catalase. J. Expt. Bot. 32, 93, 1981.

24. BRADFORD M.M. A rapid and sensitive method for the quantitation of microgram quantities of protein utilizing principle of proteine-dye binding. Anal. Biochem. 72, 248, 1976.

25. KANDZIORA-CIUPA M., CIEPAL R., NADGÓRSKASOCHA A., BARCZYK A. A comparative study of heavy metal accumulation and antioxidant responses in Vaccinium myrtillus L. leaves in polluted and non-polluted areas. Environ. Sci. Pollution Res. 20, 4920, 2013.

26. LI Y., PAN T., YU D., QIU D. Effects of simulated acid rain stress on the PS II reaction center and free radical metabolism in leaves of longan. Acta Ecol. Sinica 32, 7866, 2012.

27. KWON K-CH., VERMA D., JIN S., SINGH N.D., DANIELL H. Release of proteins from intact chloroplasts induced by reactive oxygen species during biotic and abiotic stress. PLOS One. 8, (6), e67106, 2013. 
28. ROY CH., SENGUPTA D.N. Effect of short term $\mathrm{NaCl}$ stress on cultivars of S. lycopersicum: A comparative biochemical approach. J. Stress Physiol. Biochem. 10, 60, 2014.

29. GLATZEL G., GEILS B.W. Mistletoe ecophysiology: hostparasite interactions. Botany 87, 10, 2009.

30. VICAS S. I., RUGINĂ D., SOCACIU C. Comparative study about antioxidant activities of Viscum album from different host trees, harvested in different seasons. J. Medicinal Plants Res. 5, 2237, 2011.

31. MUELLER R.C., GEHRING C.A. Interactions between an above-ground plant parasite and below-ground ectomycorrhizal fungal communities on pinyon pine. J. Ecology 94, 276, 2006.

32. SANGÜESA-BARREDA G., LINARES J.C., CAMARERO J.J. Drought and mistletoe reduce growth and water-use efficiency of Scots pine. Forest Ecol. Manage. 296, 64, 2013.

33. BELL T.L., ADAMS M.A. Attack on all fronts: functional relationships between aerial and root parasitic plants and their woody hosts and consequences for ecosystems. Tree Physiol. 31, 3, 2010.

34. VELLOSILLO T., VINCENTE J., KULASEKARAN S., HAMERG M., CASTRESANA C. Emerging complexity in reactive oxygen species production and signaling during the response of plants to pathogens. Plant Physiol. 154, 444, 2010.

35. KWON C., PANSTRUGA R., SCHULZE-LEFERT P. Les liaisons dangereuses: immunological synapse formation in animals and plants. Trends Immunol. 29, 159, 2008.

36. NINEMETS Ü. Responses of forest trees to single and multiple environmental stresses from seedlings to mature plants: Past stress history, stress interactions, tolerance and acclimation. Forest Ecol. Management 260, 1623, 2010.

37. RAI R., AGRAWAL M. Evaluation of physiological and biochemical responses of two rice (Oryza sativa L.) cultivars to ambient air pollution using open top chambers at a rural site in India. Sci. Total Environ. 407, 679, 2008

38. HUSSAIN M.I., REIGOSA M.J. Higher peroxidase activity, leaf nutrient contents and carbon isotope composition changes in Arabidopsis thaliana are related to rutin stress. J. Plant Physiol. 171, 1325, 2014

39. REY P., SANZ-BARRIO R., INNOCENTI G., KSAS B., COURTELLIE A., RUMEAU D., ISSAKIDIS-BOURGUET E., FARRAN I. Overexpression of plastidial thioredoxins $f$ and $m$ differentially alters photosynthetic activity and response to oxidative stress in tobacco plants. Plant Physiol. 4, 390, 2013.

40. KIM S.G., WANG Y., LEE K.H., PARK Z.-Y., PARK J., WU J., KWON S.J., LEE Y.H., AGRAWAL G.K., RAKWAL R., KIM S.T., KANG K.Y. In-depth insight into in vivo apoplastic secretome of rice-Magnaporthe oryzae interaction. J. Proteomics 78, 58, 2013

41. RADWAN D.E.M., FAYEZ K.A., MAHMOUD S.Y., LU G. Modifications of antioxidant activity and protein composi- tion of bean leaf due to Bean yellow mosaic virus infection and salicylic acid treatments. Acta Physiol. Plant. 32, 891, 2010.

42. NATH K., KUMAR S., POUDYAL R.S., YANG Y.N., TIMILSINA R., PARK Y.S., NATH J., CHAUHAN P.S., PANT B., LEE CH. Developmental stage-dependent differential gene expression of superoxide dismutase isoenzymes and their localization and physical interaction network in rice (Oryza sativa L.). Genes Genomics 36, 45, 2014.

43. PATYKOWSKI J., URBANEK H. Activity of enzymes related to $\mathrm{H}_{2} \mathrm{O}_{2}$ generation and metabolism in leaf apoplastic fraction of tomato leaves infected with Botrytis cinerea. J. Phytopathol. 151, 153, 2003

44. GAJWESKA E., SŁABA M., ANDRZEJEWSA R., SKŁODOWSKA M. Nickel-induced inhibition of wheat root growth is related to $\mathrm{H}_{2} \mathrm{O}_{2}$ production, but not to lipid peroxidation. Plant Growth Regul. 49, 95, 2006.

45. O'BRIEN J.A., DAUDI A., FINCH P., BUTT V.S., WHITELEGGE J.P., SUDA P., ASUBEL F.M., BOLWELL G.P. A peroxidase-dependent apoplastic oxidative burst in cultured arabidopsis cells functions in MAMP-elicited defense. Plant Physiol. 158, 2013, 2012.

46. SUNDARAVELPANDIAN K., CHANDRIKA N.N.P., SCHMIDT W. PFT1, a transcriptional mediator complex subunit, controls root hair differentiation through reactive oxygen species (ROS) distribution in Arabidopsis. New Phytologist 197, 151, 2013.

47. PASSARDI F., TOGNOLLI M., De MEYER M., PENEL C., DUNAND C. Two cell wall associateed peroxidases from Arabidopsis influence root elongation. Planta 223, 965, 2006.

48. ZILLE A., CARMEN L.D., KIM S-Y., CAVACO P.A. SWP4.1 : Functionalisation of cellulosic fibres : characterization of laccase oxidation of lignosulfonates in presence of lignocellulosic substrates. BIORENEW http://hdl.handle. net $/ 1822 / 25426.2007$

49. DELAUNIOS B., JEANDE P., CLĖMENT CH., BAILLIEUL F., DOREY S., CORDELIER S. Uncovering plantpathogen crosstalk through apoplastic proteomic studies. Front. Plant Sci. 5, 1, 2014.

50. VICAS S.I., RUGINĂ D., SOCACIU C. Antioxidant activity of European mistletoe (Viscum album). In: Rao V, editor. Phytochemicals as nutraceuticals - global approaches to their Role in nutrition and health. Rijeka, Croatia, Tech, 115, 2012.

51. KIM B-K., PARK K-Y., BAN Y-J., CHO E-J. Protective potential of mistletoe (Viscum album coloratum) against oxidative stress and cellular premature senescence. FASEB Journal 21, 1084, 2007.

52. KIM B-K., CHOI M-J., PARK K-Y., CHO E-J. Protective effects of korean mistletoe lectin on radical-induced oxidative stress. Biol. Pharm. Bull. 33 (7), 1152, 2010. 